Global Conferences Series:

Social Sciences, Education and Humanities (GCSSSEH), Volume 2, 2019

The $2^{\text {nd }}$ International Conference on Sustainable Development \& Multi-Ethnic Society

DOI: https://doi.org/10.32698/GCS.0164

\title{
Comparing the Relationship Between Parenting Styles of High Education Level of Parents with the Level of Emotional Intelligence of Preschool Children
}

\author{
Siti Rahayu Isha ${ }^{1} \&$ Nordin Mamat ${ }^{2}$ \\ ${ }^{12}$ Sultan Idris Education University, MALAYSIA \\ E-mail: rahayu.isha@fpm.upsi.edu.my
}

\begin{abstract}
The aims of this study to determine the relationship between parenting styles of parents with higher education level with the level of preschool children's emotional intelligence. The survey method was used in this study with randomly selected the location at a district of Selangor. The samples of this study consist of 50 preschool children aged six years old and have parents with higher education level. Three types of instruments were used in this study, which is Parenting Practices Questionnaire (PPQ) and Active Parenting Publisher (APP) to identify the types of parenting styles of parents with higher education level, whereas The Sullivan Emotional Intelligence Scale for Children (EISC) to identify the level of preschool children's emotional intelligence. This study also uses Berkeley Puppet Interview (BPI) as an intermediate medium when collecting data together with the subjects of the study. Descriptive analysis describes the level of preschool children's emotional intelligence, while inferential analysis involves Pearson correlation test to explain the relationship between two variables. The findings showed that parents with higher education level mostly practices an authoritarian parenting style, while overall level of preschool children's emotional intelligence are moderate. Pearson correlation analysis showed that there is significant relationship between all parenting styles (authoritarian, authoritative, permissive) with the level of preschool children's emotional intelligence. The conclusion from this study showed that parenting styles does affects the level of preschool children's emotional intelligence.
\end{abstract}

Keywords: Early childhood, emotional intelligence, parenting styles

\section{Introduction}

The level of parental education is strongly related to children's positive outcomes in various fields including school readiness, social activities, and academic achievement. Therefore, children with well-educated parents have a great opportunity to gain access to the best achievement and social resources (Nord, C., \& West, J., 
2001). In this regard, the level of parental education can influence the parenting style they adopt and the well-being of their children. This is because higher education parents tend to be more involved in children's lives (Rosenfeld, 2008), enriching their lives with additional curriculum activities, academic books, cognitive stimulation and high educational expectations.

\section{Problem Statements and Literature Review}

Even though the level of parental education is strongly related to children's development, however, this situation does not give children a chance to experience the process of learning through trial and error because everything has been monopolized by their parents (Rosemond, 2014). At the same time, these parents also tend to use negative disciplinary techniques, such as verbal and physical punishment (Hair, 2007).

After the years, the age of busy parents with a life of adulthood that has made them less focus and monitoring on their children. In the 21 st century there have been many educated parents who have turned their parenting style into a new parenting style of helicopter parenting and sergeant parenting style (drill sergeant parenting) have been cited by Love and Logic Parenting authors Charles Fay and Foster Cline (Cline \& Fay, 1993).

This helicopter parenting style is defined as the parents who have always imagined the lives of children like helicopters. This situation indicates that parents are overly involved in children's life thus promoting a lack of responsibility, disturbing children's independence, and children's autonomy (Sclafani, 2012).

While the sergeant parenting style practices is defined as parents who always give instructions, rules and punishments to children such as sergeants who train in the army. This situation shows that parents want children to always follow the rules and follow the instructions. If the child does not obey the instructions and rules then the punishment will be used as a means of removal.

The parenting style mentioned by Charles Fay and Foster Cline is in line with Baumrind's (1966) parenting style, namely, authoritarian, authoritarian, and permissive. In general, the parenting style of higher education parallels the authoritarian and permissive parenting style. However, these parents are also likely to adopt an authoritative parenting style. In summary, there are three types of parenting styles as illustrated in table 1.1 .
Commonality of three types of parenting styles Charles Fay and Foster Cline's with Diana Baumrind's parenting style

Table 1.1 Commonality of three types of parenting styles Charles Fay and Foster Cline's with Diana Baumrind's parenting style

\begin{tabular}{|c|c|c|c|}
\hline & \multicolumn{3}{|c|}{ Three Types of Parenting Styles } \\
\hline $\begin{array}{c}\text { Diana } \\
\text { Baumrind } \\
\text { (Parenting } \\
\text { Model) }\end{array}$ & Authoritative & Authoritarian & Permissive \\
\hline Explanation & $\begin{array}{l}\text { Control is } \\
\text { achieved } \\
\text { through the } \\
\text { use of rigid } \\
\text { but fair } \\
\text { arguments as } \\
\text { a basis for } \\
\text { 'moderation' } \\
\text { in open } \\
\text { negotiations } \\
\text { together using } \\
\text { positive } \\
\text { reinforcement. }\end{array}$ & $\begin{array}{l}\text { Strict control } \\
\text { is maintained } \\
\text { through strict } \\
\text { rules. The rule } \\
\text { is usually } \\
\text { enforced by } \\
\text { threats and } \\
\text { punishments }\end{array}$ & $\begin{array}{c}\text { Use } \\
\text { reasoning, } \\
\text { manipulation } \\
\text { and / or } \\
\text { corruption as } \\
\text { a means to } \\
\text { achieve some } \\
\text { level of } \\
\text { control }\end{array}$ \\
\hline $\begin{array}{c}\text { Charles Fay } \\
\text { dan Foster } \\
\text { Cline } \\
\text { (Authors of } \\
\text { Love and } \\
\text { Logic } \\
\text { Parenting } \\
\text { Book) } \\
\end{array}$ & Consultant & Drill Sergeant & Helicopter \\
\hline Explanation & $\begin{array}{l}\text { Parenting } \\
\text { style that } \\
\text { provides } \\
\text { guidance and } \\
\text { consulting } \\
\text { services for } \\
\text { children }\end{array}$ & $\begin{array}{l}\text { A parenting } \\
\text { style that has } \\
\text { always been a } \\
\text { rule and a rule } \\
\text { in children's } \\
\text { lives }\end{array}$ & $\begin{array}{l}\text { The parenting } \\
\text { style that has } \\
\text { always } \\
\text { envisioned a } \\
\text { child's life, } \\
\text { and protect } \\
\text { them from } \\
\text { the problems } \\
\text { of the world } \\
\text { in which they } \\
\text { live }\end{array}$ \\
\hline
\end{tabular}

Educated parents raise their children in an environment of high academic achievement and high expectations. In addition, these parents are capable of engaging in a variety of additional curriculum activities that encourage children to actively participate (Teachman, 1987). In this context, parents consider that their frequent intervention in children's academic activities, co-curriculum and social life can ensure that the child's individual needs are fully met (Bernstein \& Triger, 2013).

In general, having a background in education especially in higher education indicates that one has academic achievement, excellence, competitiveness (Rosendfeld, 2008), and often rules and actively and actively 
engages (Sclafani, 2012) in all matters to achieve the objectives,

The statement shows that the attitude of someone with a higher education background is synonymous with one of the parenting styles of Baumrind's authoritarian parenting model. Therefore, parents with a higher educational background can be said to adopt authoritarian parenting styles (Sclafani, 2012). However, researchers believe that, higher education parents are more likely to adopt authoritative or permissive parenting styles.

Given the drastic growth and development of children, it is important to look at the parenting-style relationship practiced by well-educated parents on the development of early childhood emotional intelligence levels. This is because, children should be act, think and behave like children, and should not be too perfect, versatile in all things or treated and treated as adults (Rosenfeld, 2008).

Recent studies have shown that children with welleducated parents of this age can be seen as they force their children to learn all the time in order to make their children the best child at an early age (PAMA, 2017). This is further reinforced by a recent study showing that parents with stress and anxiety have a positive relationship with the negative parenting style they practice.

Therefore, the involvement of a highly educated parent in the life of children especially in the academic field, is seen as a dangerous trend (Honore, 2008). Because of this, parents feel that engaging children in a variety of activities is intended to avoid the risk of boredom (Bernstein \& Triger, 2010).

Looking at the broader scope, the findings of previous studies show that nine out of 30 parents prioritize reputation and academic achievement in choosing kindergartens for their children (Badzis, 2003). In contrast, only two out of 30 parents prioritize children's happiness and fun in the process of choosing kindergarten for their children.

This situation clearly shows that these highly educated parents do not take into account the children's emotions and emotions but rather their interests as they have the right to determine the children's future (Honore, 2008). Moreover, parents of these groups also emphasize the egobased standard of care for the image and background of their higher education that can be questioned by society if their children's achievement is compromised.

Farell (2015) states in his study that the majority of literature reviews have supported the need for a positive relationship between parenting style and children's emotional intelligence. However, he said there is rarely any research on the relationship of parenting style with the level of emotional intelligence specific to preschool children.

In this regard, the researcher wants to further his research by looking at the parenting-style relationship practiced by parents with a higher education background in the level of emotional intelligence of kindergarten children in Selangor.

\section{Research Objectives}

The main objective of this study was to prove that the parenting style practiced by highly educated parents is related to the level of emotional intelligence of kindergarten children in Selangor. The objective is to identifying the relationship of authoritarian, authoritative and permissive parenting styles to the level of emotional intelligence of kindergarten children in the Petaling Utama district of Selangor.

\section{Research Methodol}

A quantitative approach with survey design was used in this study. The survey method was used in this study with randomly selected the location at a district of Selangor. The samples of this study consist of 50 preschool children aged six years old and have parents with higher education level. Three types of instruments were used in this study, which is Parenting Practices Questionnaire (PPQ) and Active Parenting Publisher (APP) to identify the types of parenting styles of parents with higher education level, whereas The Sullivan Emotional Intelligence Scale for Children (EISC) to identify the level of preschool children's emotional intelligence. This study also uses Berkeley Puppet Interview (BPI) as an intermediate medium when collecting data together with the subjects of the study. Descriptive analysis describes the level of preschool children's emotional intelligence, while inferential analysis involves Pearson correlation test to explain the relationship between two variables.

Descriptive analysis explains the level of emotional intelligence of kindergarten children, while inference analysis involves a Pearson correlation test explaining the relationship between study variables. The researcher carried out the methodology used in this study by touching in detail and detail including study design, population and sampling design, study area, survey gauge, score scoring, study procedure, pilot study and final data analysis. Therefore, in order to obtain valid, quality and accountable research 
results, proper and proper procedures need to be implemented with prudence.

\section{Findings}

In this study, researchers have identified whether there is a relationship between parental style of higher education (authoritarian, authoritative, permissive) and emotional intelligence level (knowing emotion, knowing emotion, knowing emotion, knowing emotion) kindergarten in Petaling Utama area. The independent variables of authoritarian parenting style will be tested for whether there is a significant relationship with the dependent variable, the level of emotional intelligence. Based on hipotesis:

\section{Hypothesis null 1: There is no significant relationship between authoritarian parenting style and level of emotional intelligence of kindergarten children in Petaling Utama area}

Table 1 shows the results of the correlation analysis between authoritarian-type parenting style and kindergarten children's emotional intelligence level, found Pearson correlation, $r=$ 0.757. This suggests that the association between authoritarian-type parenting styles and preschool children's emotional intelligence is high.

Table 1: Correlation Relationship Analysis Between Autoritarian Parenting Style With Respondent Emotional Intelligence Levels $(n=50)$

\begin{tabular}{cccc}
\hline & & $\begin{array}{c}\text { Parenting } \\
\text { styles } \\
\text { Autoritarian }\end{array}$ & $\begin{array}{c}\text { Emotional } \\
\text { Intelligence }\end{array}$ \\
\hline $\begin{array}{c}\text { Emotional } \\
\text { Intelligence }\end{array}$ & $\begin{array}{c}\text { Pearson } \\
\text { Correlation } \\
\mathrm{r}\end{array}$ & $0.757^{* *}$ & 1 \\
& & 0.000 & \\
& $\begin{array}{c}\text { Signifikan } \\
\text { (2-tailed) }\end{array}$ & & \\
& &
\end{tabular}

$\mathrm{N}$ 50 50

** Significant at the level of understanding $=0.05$ (2-tailed)

The positive correlation coefficient means that the relationship between authoritarian-type parenting style and kindergarten children's emotional intelligence is proportional. Mean value $p=0.000<\alpha 0.05$ (2-tailed). The null hypothesis was rejected where the study found that there was a significant relationship between authoritarian type of parenting style and kindergarten children's emotional intelligence.

The independent variables of authoritative parenting style will be tested for whether there is a significant relationship with the dependent variable, the level of emotional intelligence.

Hypothesis null 2: There is no significant relationship between authoritative parenting style and level of emotional intelligence of kindergarten children in Petaling Utama area.

Table 2 shows the results of the correlation analysis between authoritative type of parenting style and the level of emotional intelligence of kindergarten children, found Pearson correlation, $r=0.783$. This suggests that the association between authoritarian-type parenting styles and preschool children's emotional intelligence is high.

Table 2: Correlation Relationship Analysis Between Autoritative Parenting Style With Respondent Emotional Intelligence Level $(\mathrm{n}=50)$

\begin{tabular}{cccc}
\hline & & $\begin{array}{c}\text { Parenting } \\
\text { Styles } \\
\text { Keibubapaan } \\
\text { Authoritative }\end{array}$ & $\begin{array}{c}\text { Emotional } \\
\text { Intelligence }\end{array}$ \\
\hline Emotional & $\begin{array}{c}\text { Pearson } \\
\text { Intelligence }\end{array}$ & $\begin{array}{c}\text { Correlation } \\
\mathrm{r}\end{array}$ & 1 \\
& & $0.783^{* *}$ & \\
& $\begin{array}{c}\text { Significant } \\
\text { (2-tailed) }\end{array}$ & & \\
& &
\end{tabular}

** Significant at the level of understanding $=0.05$ (2-tailed)

The positive correlation coefficient means that the relationship between authoritative type of parenting style and the level of emotional intelligence of kindergarten children is proportional. Mean value $\mathrm{p}=0.000<\alpha 0.05$ (2-tailed). The null hypothesis was rejected where the study found that there was a significant relationship between authoritative type of parenting style and the level of emotional intelligence of kindergarten children.

The independent variable, the permissive parenting style, was tested for whether there was a significant relationship with the dependent variable, the level of emotional intelligence.

Hypothesis null 3: There is no significant relationship between the permissive parenting style and the level of emotional intelligence of kindergarten children in the Petaling Utama area.

Table 3 shows the results of the correlation analysis between parenting style parenting style and level of emotional intelligence of kindergarten children, found Pearson correlation, $r=0.798$. This suggests that the association between permissive type parenting style and the level of emotional intelligence of kindergarten children is high. 
Table 3: Correlation Relationship Analysis Between Permissive Parenting Style with Respondent Emotional Intelligence Level $(n=50)$

\begin{tabular}{|c|c|c|c|}
\hline & & $\begin{array}{l}\text { Parenting } \\
\text { Styles } \\
\text { Permissive }\end{array}$ & $\begin{array}{c}\text { Emotional } \\
\text { Intelligence }\end{array}$ \\
\hline \multirow{5}{*}{$\begin{array}{c}\text { Emotional } \\
\text { Intelligence }\end{array}$} & Pearson & $0.798^{* *}$ & 1 \\
\hline & $\begin{array}{c}\text { Correlation } \\
\mathrm{r}\end{array}$ & & \\
\hline & & 0.000 & \\
\hline & $\begin{array}{l}\text { Significant } \\
\text { (2-tailed) }\end{array}$ & & \\
\hline & $\mathrm{N}$ & 50 & 50 \\
\hline
\end{tabular}

The positive correlation coefficient means that the relationship between permissive type parenting style and the level of emotional intelligence of kindergarten children is proportional. Mean value $\mathrm{p}=0.000<\alpha 0.05$ (2-tailed). The null hypothesis was rejected where the study found that there was a significant relationship between parenting style of permissive type and level of emotional intelligence of kindergarten children.

\section{Discussion}

Through this study, the findings of the study were analyzed based on each domain in the Mayer-Salovey emotional intelligence model to look at possible relationships between parenting styles. The strength of the relationship between these four domains of emotional intelligence and the parenting style of higher education is estimated using the power scale. The findings of the study show that children are aware of the emotions of kindergarten children and that their relationship to authoritarian parenting style reflects a positive correlation scale, where the relationship between emotionally and emotionally parenting styles is directly proportional.

Under the significance level of 0.05 was chosen and a correlation value of $\mathrm{r}=0.590$ obtained between 0.50 and 0.70. A coefficient of 0.50 to 0.70 indicates that the relationship between the two variables is moderate. Whereas $\mathrm{p}$ values were smaller than 0.05 which was 0.000 and showed that there was a significant relationship between levels of emotion recognition and authoritarian parenting style.

Further, for the domain of knowing control of children's kindergarten and its relationship to authoritarian parenting style, the findings show a positive correlation scale scale where the relationship between emotionally and emotionally parenting style is directly proportional.
This study contributes to the theories used by the researchers in this study, two theories that underpin parentchild relationships, Bowlby's Theory of 1982 (1982) and Baumrind's Parenting Model (1966) which illustrate the emotional connection between parents with children in addition to the quality of emotional bonding that has been established from both sides.

While in the theory of emotional intelligence, the model under discussion is the Mayer-Salovey (1997) Fourbranch Emotional Intelligence model. This study has proven that the selection of parenting styles mentioned by Baumrind in its Parenting Style Model in determining children's emotional well-being is crucial. The Mayer-Salovey (1997) Four-branch Model of Emotional Intelligence, supported by extensive research, has shown that success in life depends on a variety of intelligences such as those described in Howard Gardner's Theory of Multiple Intelligence (1983) and not purely intellectual intelligence.

\section{Conclusion}

In conclusion, based on this statement is further reinforced by studies that have shown that individuals with high intellectual ability fail to become good leaders because of their failure to manage emotions in the workplace. According to the study, the level of emotional intelligence of the kindergarten children at a moderate level has a positive and strong relationship with the three parenting styles and the strongest relationship is the permissive type of parenting style.

\section{References}

[1] Badzis, M. (2003). Teachers' and parents' understanding of the concept of play in child development and education. Retrieved from http://wrap.warwick.ac.uk/2502/

[2] Baumrind, D. (1966). Effects of authoriative parental control on child behavior. Child Development, 37(8975), 887-907. https://doi.org/10.2307/1126611

[3] Baumrind, D. (1967). Child Care Practices anteceding three patterns of preeschool behavior. Genetic Psychology Monographs, 75(1), 43-88.

[4] Baumrind, D. (1991). Effective parenting during the early adolescent transition. In P.A. Cowan \& E. M. Hetherington (Eds.), Advances in family research (Vol. 2). Hillsdale, NJ: Erlbaum.

[5] Bernstein, G., \& Triger, Z. (2010). Over-Parenting. UC Davis Law Review, 44(4),1221-1279. Retrieved from http://heinonlinebackup.com/holcgibin/get_pdf.cgi?handl $\mathrm{e}=$ hein.journals/davlr44\&section $=37$ 
[6] Bernstein, G., Triger, Z., Journal, P., \& Vol, E. (2013). 1221 Electronic copy available at: http://ssrn.com/abstract=1588246, 41(4), 1221-1279.

[7] Bowlby, J. (1969). Attachment and loss. Attachment (Vol.1). https://doi.org/10.1177/000306518403200125

[8] Bowlby, J., \& Zeanah, C. H. (1988). A secure base: Parent-child attachment and healthy human development. The Journal of Nervous and Mental Disease (Vol. 178). https://doi.org/10.1097/00005053-199001000-00017

[9] Bowlby, J. (1982). ATTACHMENT AND LOSS: Retrospect and Prospect. American Journal of Orthopsychiatry, 52(4), 664-678. https://doi.org/10.1111/j.1939-0025.1982.tb01456.x

[10] Cline, F. \& Fay, J. (1993). Parenting teens with love and logic. Colorado Springs, CO: Pinon Press.

[11] Farrell, G. (2015). The Relationship Between Parenting Style and the Level of Emotional Intelligence in Preschool-Aged Children, Philadelphia College of Osteopathic Medicine

[12] Goleman, D. (1995). Emotional intelligence. Personality and Individual Differences, 9(5), 1091-1100. https://doi.org/10.1016/j.paid.2003.12.003

[13] Grolnick, W. S., \& Seal, K. (2008). Pressured Parents, Stressed-Out Kids. Prometheus Books. Retrieved from www.prometheusbooks.com

[14] Hair E., Halle T., Terry-Humen E., Lavelle B., Calkins J. (2006), Children's School Readiness in the ECLS-K: Predictions to Academic, Health, and Social Outcomes in First Grade, Early Childhood Research Quarterly, 21, 431-54.

[15] Honore C., (2008). Under Pressure. Orion Books.

[16] Rosemond J., (2014, November). Parental Hovering Delaying Kids' Adulthood. Hartford Courant, 1-2. Retrieved from http://www.courant.com/features/hcrosemond-on-helicopter-parents-20141111-story.html

[17] Mayer, J. D., and Salovey, P. (1993). The intelligence of emotional intelligence. Intelligence 17(4): 433-442.

[18] Mayer, J. D., Salovey, P., \& Caruso, D. R. (2004). Emotional intelligence: Theory, findings, and implications. Psychological Inquiry, 60, 197-215.

[19] Nord, C., J. Lennon, B. Liu \& K. Chandler (1999). Home literacy activities and signs of children's emerging literacy, 1993 and 1999. Washington, D.C.: U.S. Department of Education, Office of Educational Research and Improvement, NCES 2000-026.

[20] Rosenfeld, B. A., \& Wise, N. (2001). The OverScheduled Child:Avoiding the Hyper-Parenting Trap.

[21] Sclafani, J. D. (2012). The educated parent 2: Child rearing in the 21 st century. The educated parent 2: Child rearing in the $21 \mathrm{st}$ century. Retrieved from http://search.proquest.com/docview/1312427313?account $\mathrm{id}=14777 \% 5 \mathrm{Cnhttp}: / / \mathrm{xv} 91 \times 6 \mathrm{~cm} 3 \mathrm{j}$. search.serialssolutions. com/?ctx_ver=Z39.882004\&ctx_enc=info:ofi/enc:UTF8
\&rfr_id=info:sid/PsycINFO\&rft_val_fmt=info:ofi/fmt:ke v:mtx:book\&rft.genre=book\&rft.jtitle $=\&$ rft.atitl

[22] Teachman, J. D. (1987) Family background, educational resources and educational attainment, American Sociological Review, 52, 548-557. 